\title{
Research on the Countermeasures to Strengthen the Management of Intellectual Property Right in Universities in China
}

\author{
Shen Yang \\ Wuhan University of Technology \\ Wuhan, China
}

\begin{abstract}
The future competition is the competition of intellectual property rights, and China is working hard to build a strong intellectual property country. The IPR management of universities in China has been initially developed and achieved remarkable results. However, some universities still have problems in the protection of intellectual property rights, such as weak protection awareness and insufficient work input. However, there are low quality and low conversion rate existing in the university's knowledge achievements. Therefore, we should increase the emphasis on IP management and the importance of IP management, introduce professional talents, set up scientific management institutions, raise funding and support, and promote the development and improvement of intellectual property management in China's universities.
\end{abstract}

Keywords-Intellectual property strategy; Intellectual property management; Transformation of results; Patent quality

\section{INTRODUCTION}

The report of the 19th National Congress of the Communist Party of China stated that it is necessary to "advocate an innovation culture and strengthen the creation, protection and use of intellectual property rights." In his speech at the Boao Forum for Asia, President Xi pointed out that it is necessary to "strengthen the protection of intellectual property rights. This is the most important content for improving the system of property rights protection and the biggest incentive to improve China's economic competitiveness." universities are the gathering place of knowledge, shouldering the heavy responsibility of scientific research and technological innovation, and contributing a great deal of knowledge and technology to the whole country and society. According to statistics, $70 \%$ of the major scientific and technological achievements affecting the human lifestyle are generated in universities, and many well-known enterprises such as Founder and Tsinghua Tongfang have emerged in China [1]. However, at present, in some universities, due to insufficient attention to intellectual property work, scientific research personnel have a weak sense of intellectual property legal protection, resulting in independent intellectual property rights. The loss of scientific research results has occurred from time to time, and it is difficult to safeguard rights after patent infringement occurs. At the same time, in the intellectual property work of universities, there are not many intellectual property rights patents with scientific and technological innovation, and the systemic and integration of intellectual property work is not enough, which seriously affects the social service functions of universities[2]. Therefore, it is especially important to strengthen the management of intellectual property in universities in China.

\section{THE START AND DEVELOPMENT OF INTELLECTUAL PROPERTY MANAGEMENT IN CHINA'S UNIVERSITIES}

\section{A. The relevant laws and regulations at the national level are} gradually improved

The "Copyright Law", "Patent Law", "Trademark Law", "Anti-Unfair Competition Law", etc., have made general provisions on the protection of copyrights in college works and the application and protection of patents and trademarks. In 1999, the Ministry of Education issued the "Regulations on the Protection of Intellectual Property Rights in universities" in the form of ministerial orders, which clarified the duties, tasks, work initiatives of intellectual property protection and management in universities, protected the intellectual property rights of universities, and stimulated the creative enthusiasm of faculty has played a positive role. In 2004, the Ministry of Education and the State Intellectual Property Office jointly issued the "Several Opinions on Further Strengthening the Intellectual Property Work of universities", proposing to understand and carry out intellectual property work from a strategic perspective, and to make the intellectual property work of universities more direct and finer[3].

\section{B. The level of intellectual property work in universities continues to improve}

According to statistics, nearly $90 \%$ of the " 211 " universities have formulated special rules and regulations for intellectual property rights, and a few universities have also formulated intellectual property strategies at the school level to guide the intellectual property protection work of each school with remarkable results. Taking Hubei Province as an example, starting from 2014, Hubei Province had launched the intellectual property promotion project of universities, aiming to improve the level of intellectual property management in universities, stimulate innovation and creation of universities, and accelerate the use of intellectual property achievements in universities.

In 2017 , the province's college patent applications and authorizations increased by $14.8 \%$ and $21.5 \%$ respectively. Among them, the invention patent application and authorization increased by $18.7 \%$ and $45.9 \%$ respectively. There are 3 universities with over 1,000 invention patent applications, among which Huazhong University of Science and Technology has 1,606 invention patent applications, 
ranking first in the province's universities. For the total number of valid patents in universities across the country, Huazhong University of Science and Technology ranked 10th in the country with a total of 5,082 effective patents. Wuhan University ranked 26th in the country with a total of 3,570 effective patents; the effective total number of patents of Wuhan University of Technology was 2,955, ranking 36th in the country.

\section{$C$. The role of the source of knowledge innovation in universities is increasingly prominent}

Universities have always been an important force in China's scientific and technological innovation. The data shows that during the "Twelfth Five-Year Plan" period, Chinese universities had taken the lead in undertaking more than $80 \%$ of the National Natural Science Foundation projects and a large number of major national scientific and technological tasks such as "973" and " 863 ", and led the construction of the National "Twelfth Five-Year Plan" . Among the major science and technology infrastructures, the national key laboratories relying on universities accounted for $60 \%$ of the total, and the national science and technology three awards accounted for more than $60 \%$ of the total awards. A number of landmark research results with significant influence have been made in the research fields of dark matter, stem cells and supercomputers. According to relevant statistics of the State Intellectual Property Office, in 2015, the domestic authorization amount of invention patents in China was 263,000 , of which 29,900 were universities, accounting for 11.4\%. During the "Twelfth Five-Year Plan" period, the total amount of science and technology funds in China's universities reached 593.6 billion yuan, which is an increase of about $78 \%$ compared with the "11th Five-Year Plan" period[4]. "In the context of the country's continuous strengthening of science and technology investment, the establishment of a good patent conversion system has become more and more important." Yang Xuri, dean of Beijing Qiangguo Intellectual Property Research Institute said.

\section{THE DEFECTS AND SHORTCOMINGS OF INTELLECTUAL PROPERTY MANAGEMENT IN UNIVERSITIES}

\section{A. Weak awareness of intellectual property protection in universities}

China has begun to implement the national intellectual property strategy in depth, but most colleges lack intellectual property strategy awareness and do not incorporate intellectual property into the school's development strategy. This leads to a weak awareness of the general intellectual property rights of teachers and students in universities, and lacks common sense of intellectual property. Nearly $90 \%$ of the " 211 " colleges have developed special rules and regulations on intellectual property rights, a few universities have also developed intellectual property strategies at the school level. However, there are still a large number of universities and colleges that have not set up independent intellectual property courses. According to statistics, only Up to $10 \%$ of universities have established intellectual property institutions, and only $13 \%$ of universities have IP-related courses. Since China's intellectual property system is still at an early stage of development, some university researchers have not fully understood the connotation of intellectual property protection[5]. Naturally, they cannot systematically take protective measures, and even their own interests are encroached but not self-contained. Know the situation. This led some inventors to rush to publish articles or results after obtaining research results, without first applying for patent protection. When they later think of applying for a patent, they will inevitably disclose the technical content because of the publication of articles or results identification, which will result in the loss of patent applications. Novelty without protection. Some of the research groups lack effective management of patents, and often fail to respond to the review opinions within the prescribed time limit, resulting in the patents being considered for withdrawal, and sometimes the patent rights are lost because the annual fees are not paid in time.

\section{B. The quality of intellectual property achievements in universities is low}

The low quality of patents in universities is the most prominent problem in the management of intellectual property in universities in China. It is mainly reflected in the following aspects: First, the scope of patent claims is too small, and competitors can easily bypass the scope of claims, resulting in low commercial value of patents; It is the short period of validity of patents. Most of the effective invention patents in Chinese universities are only valid for 3 to 5 years. Compared with corporate patents, the validity period of patents is too short. Third, the number of international patent applications is small. According to WIPO statistics, international Among the top 50 universities with patent applications, there are 30 universities in the United States, 10 universities in Japan, and no university in China. The number of patents in universities has been greatly developed, but the quality has not kept up, and the number of high-quality patents has made it awkward.

The formulation of university policies is the baton of all aspects of the operation of universities. Once the baton is biased, it is not conducive to the long-term development of the school. The reform and implementation of the post employment system and performance reward system in local universities has doubled the growth of scientific research results, but at the same time there is a tendency to unilaterally pursue quantity but neglect quality improvement[6]. Although the number of intellectual property rights has been greatly improved, authorization Post-conversion rates are generally low, and the ultimate goal of universities to encourage intellectual property is to create value. Therefore, for the formulation of intellectual property management policies in universities, some universities have problems such as quick success and quick success, which restricts the sound development of intellectual property management in universities. 


\section{The conversion rate of intellectual property achievements in universities is low}

According to the report, the effective patent implementation rate in China was $57.9 \%$ in 2014 . From the perspective of the types of patent holders, the patent implementation rate of enterprises is relatively high at $68.6 \%$, while the patent implementation rate of universities is only 9.9\%; The total proportion of patents that are placed on the market and placed on the market is $42.9 \%$, and universities only account for $1.7 \%$. In terms of the successful licensing of patents, the total effective patent ratio is $9.9 \%$, and colleges only account for $2.1 \%$. In terms of the percentage of patents that have been successfully transferred to others, the total is $5.5 \%$ and the universities are $1.5 \%$. These data fully show that the conversion rate of intellectual property achievements in universities in China is low.

There are many factors that hinder the transformation of intellectual property market in universities, such as lack of intellectual property transformation awareness, lack of professional talents in intellectual property transformation, imperfect property rights system, unreasonable income distribution, imperfect evaluation and incentive mechanism for scientific research personnel, and encouragement of intellectual property transformation. Imperfect, the market maturity of intellectual property itself is not high, the lack of specialized intellectual property to cultivate and transform institutions, and the insufficient capital investment to promote the transformation of intellectual property rights. Therefore, in the future work, it is imperative to improve the above-mentioned problems, improve the intellectual property management of universities in China, and promote the transformation of intellectual property market in China's universities.

\section{IMPROVEMENT OF INTELLECTUAL PROPERTY MANAGEMENT IN UNIVERSITIES IN CHINA}

\section{A. Increase publicity and raise awareness of the importance of intellectual property rights}

At present, the management of intellectual property rights in universities in China is not satisfactory. The reason is that some universities are not aware of the importance of intellectual property rights and the importance of intellectual property protection work. The lack of attention in thought leads to slack in the actual management work. As the main force of China's scientific and technological innovation, universities play an important role in China's economic construction. Therefore, it is necessary to take intellectual property protection involved in technological innovation as an important task. The premise of intellectual property protection is the need to understand and conceptualize the relevant knowledge involved in intellectual property[7]. Therefore, China's universities need to incorporate these intellectual property protection knowledge into their daily publicity work, so that researchers can recognize the importance of intellectual property protection and the application of intellectual property rights to protect their scientific research results.
Increase the importance of intellectual property rights and raise the awareness of intellectual property rights of all teachers and students. The specific operation method can be: for the management of universities, learn from the examples of the application of intellectual property protection in universities and colleges at home and abroad, and strengthen the knowledge in the form of training courses or meetings. Property rights awareness; for college teachers, they can use lectures and seminars to publicize and learn about intellectual property work, and guide them to combine relevant knowledge to conduct related learning; for college students, you can set up special intellectual property courses and establish intellectual property rights. Minor majors, to achieve the intersection of disciplines, form a basic knowledge system on intellectual property.

\section{B. Introduce professional talents and establish a scientific intellectual property management organization}

Because of its inherent cross-cutting, complex, and comprehensive characteristics, intellectual property requires professional talents with professional knowledge to work and manage. Intellectual property management can be divided into three types according to the professional nature. The first is the application for intellectual property rights. The main task is to help applicants to write intellectual property applications or registration documents, monitor the entire application or registration process, and ensure intellectual property rights. The second is intellectual property law, the main task is to help deal with various intellectual property legal advice and legal disputes, to prevent college intellectual property rights from being infringed. The third is intellectual property management. The main task is to help universities carry out various technological trades such as innovation incentives and signing technology licensing contracts to maximize the legitimate rights and interests of universities. These three tasks are not independent, but are intertwined. When applying for intellectual property rights, it requires both the IPR application personnel to monitor the whole process and the legal consultation of legal personnel, as well as the macro-planning guidance of IP operators. When conducting trade in intellectual property technology with enterprises, it is necessary for intellectual property management personnel to conduct technical trade negotiations, and legal personnel to escort the signed contracts to jointly maximize the interests of universities.

A good organization is to ensure that it involves the efficient operation of related work. There are many differences between China's intellectual property protection institutions and other institutions of higher education. It has certain technical and legal protection. Therefore, the management of the organization needs to have certain professional knowledge and skills and must be fully committed to the daily intellectual property protection work. The intellectual property rights of higher education institutions occupy a very important position in the intellectual property rights of all units in China. Therefore, it is necessary to strengthen the intellectual property protection institutions and management systems for higher education institutions, and establish special intellectual property management institutions to carry out systematic and comprehensive management. 


\section{Improve the quality of patents and pay attention to the transformation of intellectual property achievements in universities}

The problem of intellectual property management in China's universities generally has the problem of heavy quantity and light quality. This has resulted in a large number of patents in China's universities, but there are few igh-quality patents. In the future work of intellectual property management in universities, it is necessary to reverse this misunderstanding. Researchers should be encouraged to dare to delve into the research, and the key points and difficulties of technology should be explored to overcome the quality of scientific research. At the same time, improve the methods for assessing and assessing intellectual property rights. For different quality patents, they should be rewarded accordingly. For high-quality patents, rewards should be rewarded. For those patents that do not have much value in value, they can be rewarded or not. Reward, in order to reverse the misunderstanding of the heavy quantity and light quality of scientific research personnel.

Heavy results and light transformation are another problem in the management of intellectual property rights in universities in China. To improve the implementation rate of scientific research achievements in universities, we must first have the awareness of the transformation and implementation of results. In order to prevent scientific research from being out of touch with the market, universities can learn from enterprises. When formulating the plans and goals of scientific research and innovation, they should be market-oriented and focus on breaking through scientific research projects with technical value and commercial value, which will not only help to enhance scientific research results. The comprehensive quality also makes the research results more easily transformed. Second, we should increase the capital investment in the transformation of results. In order to transform the patents of universities into productive forces, it is necessary to undertake the specific market industry. The long period of the cycle naturally requires the investment of funds. To this end, universities should increase investment in the transformation of results, and encourage the government and enterprises to invest, in order to ensure the smooth progress of the results transformation work.

\section{CONCLUSION}

The future competition of the world is the competition of intellectual property. The management of intellectual property rights in universities in China has steadily moved from basic construction to comprehensive development. The development of intellectual property service in universities is both a necessity and a historical necessity. Chinese universities must fully recognize the importance of intellectual property rights, establish awareness of intellectual property protection and management, do a good job in intellectual property protection and management, introduce professional talents, set up scientific management institutions, increase investment and protection, and conduct national research. Contribute to development, contribute to building a strong intellectual property country, and contribute to the Chinese dream of realizing the great rejuvenation of the Chinese nation!

\section{REFERENCES}

[1] Han Yaning. Intellectual Property Issues and Countermeasures in University Science and Technology Innovation[J].Science and Technology Communication, 2014,6(16):20-21. (In Chinese)

[2] Chen Dangsheng. Research on the Countermeasures to Strengthen the Protection of Intellectual Property Rights in Colleges and Universities[J].Science Consulting,2016(07):11-12. (In Chinese)

[3] Wu Yue. Implementing the Intellectual Property Strategy of Colleges and Universities Serving the Construction of National Innovation System[J].Science and Technology of Chinese Universities,2013(04):66-67. (In Chinese)

[4] Sun Di. Intellectual Property Operation: Injecting the Source of Intellectual Property Innovation into Colleges and Universities. People's Network, Published: 2016-12-29. (In Chinese)

[5] Liu Yan. Study on the Establishment of Intellectual Property Service System in Colleges and Universities[J].Journal of Heilongjiang College of Education,2015,34(11):177-178. (In Chinese)

[6] Huang Lifang. Study on the Construction of Intellectual Property Transformation Platform in Colleges and Universities-Taking Zhejiang as an Example[J]. Journal of Legal System,2015(25):19-20. (In Chinese)

[7] Yin Kechun. Study on Technological Innovation and Intellectual Property Protection in Colleges and Universities $[\mathrm{J}]$. Cooperative Economy and Technology,2016(07):186-188. (In Chinese) 